\title{
Cambios volumétricos a edad temprana en el hormigón debido a la retracción química del cemento
}

\section{Early age volume changes in concrete due to chemical shrinkage of cement paste}

\author{
L. EBENSPERGER M., Dr. Ing.; R. BREITENBÜCHER, Dr. Ing.; R. SPRINGENSCHMID, Univ. Professor. \\ Instituto de Materiales de Construcción, Universidad Técnica de Munich, Baumbachstr. 7, D-8.000 Munich 60
}

Fecha de recepción: 9-X-91.

ALEMANIA FEDERAL

\section{RESUMEN}

Se han determinado los cambios volumétricos que ocurren en pastas de cemento, morteros y hormigones a edad temprana debido al efecto de la retracción química. Las mediciones se realizaron en probetas selladas y noselladas sumergidas bajo agua.

La retracción química en probetas no-selladas representa la cantidad de agua absorbida debido a la reacción química del cemento. Depende solamente del contenido de cemento de la probeta y no produce ningún cambio en las dimensiones de la probeta. Por el contrario, la retracción química en probetas selladas está relacionada con un cambio volumétrico real debido al efecto de la autodesecación y presiones internas. La retracción en este caso depende tanto de la restricción que imponen los áridos, como del contenido de cemento. La retracción química medida en hormigones sellados resultó ser mucho mayor que la que se espera ocurra en el hormigón, dado que en el interior del hormigón ocurre, hasta cierto grado, un equilibrio de las presiones desarrolladas.

El uso de aditivos expansivos mostró que sí es posible compensar la retracción química, pero su dosificación es muy sensible y debe definirse exactamente para cada caso en particular.

\begin{abstract}
$S U M M A R Y$
Unrestrained early age volume changes due to chemical shrinkage in cement pastes, mortars and concretes have been determined. The measurements were performed on sealed and unsealed samples which were stored under water.
\end{abstract}

The chemical shrinkage of unsealed specimens represents the amount of absorbed water due to the chemical reaction of the cement. It depends only on the cement content of the sample and does not lead to changes of the external dimensions. However the chemical shrinkage of sealed specimens is connected with a real volume change due to self-desiccation and the effect of internal pressures. The shrinkage depends in this case on the restraining effect of coarse aggregates as well as the cement content. The chemical shrinkage mesured on sealed concretes was much higher than the one expected to ocurr on concretes, because normally an equalization of pressure takes place to some extent in the interior of the concrete.

The use of expansive additives showed that they may compensate the chemical shrinkage, but its dosage is very sensitive and should be defined exactly for each case particullary.

\section{INTRODUCCIÓN}

Durante la hidratación el agua de amasado se combina químicamente con las diferentes fases del clínker, sufriendo una reducción de volúmen del orden de un $25 \%$, lo cual se denomina retracción química $(1,2)$. De los $40 \mathrm{~g}$ de agua

\section{INTRODUCTION}

During hydration water is bound chemically to the different clinker phases which results in reduction of the water volumen of about $25 \%$, called chemical shrinkage $(1,2)$. From the $40 \mathrm{~g}$ water needed for complete hydration of $100 \mathrm{~g}$ cement 
necesarios para la hidratación completa de $100 \mathrm{~g}$ de cemento, sólo 25 a $28 \mathrm{~g}$ son combinados químicamente (agua no evaporable). Esta porción lleva a una reducción volumétrica aproximada de 6-7 $\mathrm{cm}^{3}$ por cada $100 \mathrm{~g}$ de cemento $(3,4)$, valor que ha sido comprobado en mediciones volumétricas de pastas de cemento sumergidas en agua $(2,5,6)$, o mediante mediciones de densidad (2).

La retracción química es influenciada sólo ligeramente por el tipo de cemento, composición química y finura de éste. Su desarrollo depende del grado de hidratación y de la relación aguacemento $(\mathrm{a} / \mathrm{c})$. Para relaciones a/c altas, la hidratación es acelerada, causando valores de retracción más altos en los primeros días, mientras que la retracción final, después de completada la hidratación, alcanza los mismos valores que para relaciones a/c bajas. Sólo para relaciones a/c inferiores a 0,40 la retracción química final es menor, debido a una hidratación incompleta.

Ya que la retracción química es una propiedad intrínseca del cemento, la mayoría de las investigaciones se ha realizado en pastas de cemento. Para su determinación, normalmente se realizan mediciones de probetas sumergidas en condiciones no-selladas. Por otro lado, sucede que las condiciones experimentales en el hormigón difieren bastante de las existentes en la pasta de cemento. Por esto, los resultados ya conocidos en pastas de cementos no pueden ser transferidos directamente al hormigón.

La finalidad de esta investigación fue estudiar el efecto de la retracción química en hormigones. Con este propósito se midió en varias mezclas los cambios volumétricos que ocurren en condiciones selladas. A modo de poder comparar con resultados conocidos, se realizaron además mediciones en pastas de cemento y morteros en condiciones de sellado y no-sellado, permitiéndose así estudiar adicionalmente el efecto de la relación cemento/árido sobre la retracción química.

\section{ESTADO DEL ARTE}

La retracción química a edad temprana es determinada normalmente mediante la medición de cambios volumétricos o cambios de longitud de probetas sumergidas en agua o curadas en aire. Mediciones volumétricas pueden comenzar casi inmediatamente después de finalizado el mezclado (8 a $30 \mathrm{~min}$ ), lo que no es posible realizar con mediciones de longitud, dado que la probeta no puede ser desmoldada antes de 4 a 6 horas. Adicionalmente, los resultados difieren fuertemente, dependiendo si la probeta se encuentra o no sellada durante el desarrollo del ensayo. only 25 to $28 \mathrm{~g}$ are bound chemically (non evaporable water). This portion leads then to chemical shrinkage corresponding to a volume reduction of 6 to $7 \mathrm{~cm}^{3}$ per $100 \mathrm{~g}$ cement $(3,4)$. This value has been verified by volumetrical measurements on cement pastes immersed in water $(2,5,6)$ or by density measurements (2).

The chemical shrinkage is only slightly influenced by the type of cement, chemical composition and fineness. Its development depends on the degree of hydration and the w/c-ratio. For larger $w / c$ ratios the rate of hydration increases causing a larger chemical shrinkage in the first few days, whereas the final shrinkage after complete hydration reaches rearly the same values than for lower $w / c$ ratios. Only for $w / c$-ratios below 0.40 the chemical shrinkage is lower due to incomplete hydration.

Because the chemical shrinkage is a property of the cement the majority of investigations is carried out on cement paste. For its measurement normally submerged unsealed specimens are tested, where only the water volume reduction is determined. However, in concrete the boundary and experimental conditions are different to those in cement. Therefore the known results from cement pastes cannot be transfered directly to concrete.

The aim of this research was to study the effect of chemical shrinkage on concrete. For this purpose on different mixes the volume changes of sealed specimens were tested. Futhermore, in order to allow a comparison with existing results the tests were carried out also with sealed and unsealed mortars and cement pastes, which permitted additionally to study the influence of cement/aggregate ratio on chemical shrinkage.

\section{STATE OF THE ART}

Chemical shrinkage at early ages is normally determined by measurements either of volume change or length change on specimens submerged in water or cured at air respectively. Volumetrical measurements can be started soon after mixing (8 to $30 \mathrm{~min}$ ), whereas this is not possible for length changes, where the samples can be demoulded only after 4 to 6 hours. Additionally, the results depend strongly on whether the samples are sealed during storage or not. 


\section{Cambios volumétricos}

La diferencia en las mediciones volumétricas entre probetas selladas y no-selladas sumergidas bajo agua puede ser explicada si se consideran los procesos físico-químicos que ocurren en la probeta durante la hidratación. Como consecuencia de la reducción volumétrica del agua de amasado que se une químicamente, se forman internamente poros.

En experimentaciones con probetas no-selladas el agua es absorbida hasta la saturación, llenándose estos poros totalmente de agua. Este agua absorbida puede ser medida y representa el cambio de volumen del agua combinada químicamente durante la hidratación del cemento, lo que se conoce como retracción química interna (7). Esta "retracción" produce sólo variaciones mínimas en las dimensiones externas de la probeta, y normalmente es relacionada con el contenido de cemento de la probeta $\epsilon \mathrm{C}=\Delta \mathrm{V} / \mathrm{C}\left(\mathrm{cm}^{3} / 100 \mathrm{~g} \mathrm{C}\right)$.

Si la probeta es mantenida en condiciones selladas, el ingreso de agua adicional no es posible. Esto induce a que el agua en los poros sea parcialmente evacuada, produciéndose una reducción de la humedad relativa del poro, lo cual genera la llamada autodesecación o retracción autógena (1). La continuación de la hidratación será así influenciada y si la presión de vapor disminuye a un $85 \%$ de la presión de saturación, la hidratación cesará casi por completo. La disminución de la humedad relativa provoca además presiones negativas en los poros (en comparación con la presión atmosférica). Estas presiones negativas generan tensiones internas, capaces de conducir a microfisuras en la matriz, las cuales influyen a su vez en la durabilidad del hormigón $(9,10,11,12)$. El efecto global se manifiesta en una reducción en las dimensiones externas de la probeta, llamada retracción química volumétrica (7), cuya magnitud es del orden del $1 \%$ del volumen absoluto del cemento (8), y se representa normalmente como un cambio volumétrico referido al volumen inicial de la probeta $\in \mathrm{V}=\Delta \mathrm{V} / \mathrm{V}(\%)$.

\section{Cambios de longitud}

Las mediciones de cambios de longitud en probetas selladas y no-selladas son normalmente uniaxiles. Utilizando este método, varios autores $(13,14,15)$ describen el desarrollo de la retracción a edad temprana en pastas de cemento. Midiendo en conciciones selladas y noselladas, Baron (13), separó la retracción por efecto de la retracción química de aquélla por evaporación del agua, distinguiendo una curva característica de la retracción a edad temprana, la cual se divide en tres etapas (Fig. 1):

\section{Volume Changes}

The differences in volumetric measurements between sealed and unsealed specimens stored under water may be explained by considering the physico-chemical processes which take place in the samples during hydration. Internal pores are formed due to the volume reduction of mix water when it is chemically bound.

In experiments on unsealed specimens water can be absorbed until saturation and the pores are filled completely. Thus only the quantity of absorbed water is determined. This type of measurement represents the volume change of the chemical bound water due to the hydration of cement, the internal chemical shrinkage (7). This "shrinkage" however results only in a very slight change of the external dimensions. The measured volume change is related to the cement content of the sample $\in C=\Delta V / C\left(\mathrm{~cm}^{3} / 100 \mathrm{~g} \mathrm{C}\right)$.

In the case of sealed specimens no further water can penetrate into the sample and the pores will be partially emptied. This causes a reduction of the relative humidity in the pores, resulting in a so-called self-desiccation or autogeneous shrinkage (1). The continuity of hydration is influenced and if the vapour pressure decreases to about $85 \%$ of the saturation pressure, the hydration will be nearly stopped. The decrease in relative humidity also produces negative pressures in the pores (in comparison with atmospheric pressure) which cause internal stresses and may lead to internal microcracking in the matrix influencing the durability of concrete $(9$, $10,11,12)$. Due to the global effect a reduction in the external dimensions occurs, called bulk chemical shrinkage (7). It can reach about $1 \%$ of the absolute volume of cement (8). The measured volume change in this case is related to the initial volume of the sample $\in V=\Delta V / V(\%)$.

\section{Length Changes}

Length changes on sealed or unsealed specimens are usually measured uniaxial. Using this method many authors $(13,14,15)$ describe the development of early age length changes on cement pastes. By measuring under sealed and unsealed conditions Baron (13) separated the length changes due to chemical shrinkage from the shrinkage due to evaporation and gave a characteristic curve of early age shrinkage divided into three stages (Fig. 1). 


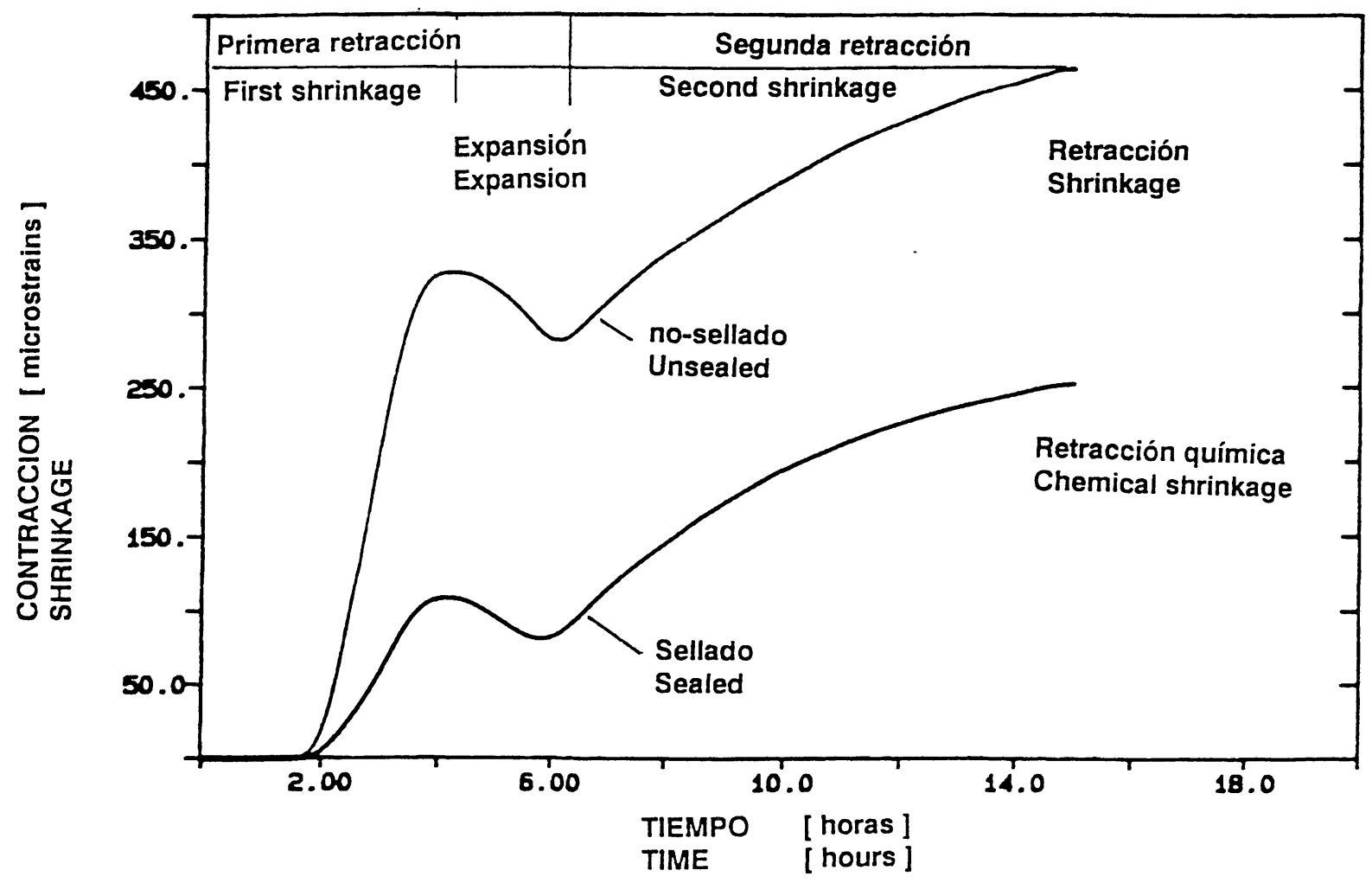

Fig. 1.-Retracción en pastas de cemento selladas y no-selladas curadas en aire (13).

Fig. 1.-Shrinkage of sealed and unsealed cement pastes cured at air conditions (13).

I. Primera retracción desarrollada antes del fraguado y durante la fase plástica, llamada "retracción plástica". Es generada principalmente por la rapidez de evaporación (en el caso de probetas no-selladas) y por la cantidad inicial de agua. Esta fase se puede prolongar hasta 6 horas y representa la mayor parte de las contracciones.

II. Le sigue un período de pequeñas deformaciones de hinchamiento que comienza entre 4 a 10 horas después del mezclado y puede prolongarse hasta 10 horas o más.

III. Segunda retracción depende principalmente de la cantidad de cemento aún no-hidratado y del efecto de la autodesecación. La influencia de la evaporación es mínima. Esta fase puede comenzar gradualmente o en forma repentina, y la rapidez de este comienzo (pendiente de la curva) se define como índice de sensibilidad (13). Dado que la segunda retracción comienza después del endurecimiento, en general una vez que el material ha logrado suficiente rigidez, se generan tensiones de tracción en la probeta, aumentándose así el riesgo de fisuración.

La comparación de los resultados obtenidos con ambos métodos de medición (volumétrico y uniaxil) muestran grandes diferencias, atribuidas principalmente a la edad de la probeta al comienzo de cada medición. La principal desventaja del método uniaxil es que no
I. First shrinkage develops before setting and during the plastic phase. It is also called "plastic shrinkage". It is governed mostly by the rate of evaporation (in case of unsealed specimens) and the initial water content. This stage can be prolonged up to 6 hours and represents the largest part of the contraction.

II. A period of small expansion follows, which can start at the age of between 4 to 10 hours after mixing and lasts in some cases 10 hours or more.

III. Second shrinkage principally depends on the amount of still unhydrated cement and selfdesiccation. The influence of evaporation is negligible. This stage can appear gradually or suddenly and its initial rate (slope of the curve) is defined as the sensitivity index (13). Because the second shrinkage occurs after setting, i.e. when the material has already an adequate rigidity, tensile stresses are caused in the samples increasing the risk of cracking.

The comparison of the results obtained with the two methods (volumetrical and uniaxial dilatometer) show large differences which are commonly attributed to the age of the specimen at the beginning of each measurement. The main disadvantage of length change measurement is 
contempla las deformaciones que ocurren en las primeras horas antes del desmoldaje.

Recientemente Komlos (14), midiendo con un dilatómetro uniaxil, pudo tomar la primera lectura a los $8 \mathrm{~min}$, pero lamentablemente él no realizó mediciones volumétricas que permitan una comparación. Brameshuber (16) pudo comparar mediciones obtenidas mediante ambos métodos, considerando para ello sólo una parte de las deformaciones volumétricas; sólo aquéllas ocurridas después de haber comenzado la medición uniaxil.

\section{Influencias en la medición de la retracción química}

1) La cantidad de agua, definida por la relación agua-cemento $(\mathrm{a} / \mathrm{c})$, es uno de los factores más importantes en la formación de los productos de hidratación y en la porosidad de la pasta.

En probetas no-selladas con una relación a/c alta se permite un mejor transporte de agua, siendo por esto la medición de la retracción química interna más exacta. Este principio fue usado por Jung (17) en los años 70 para medir la retracción química en hormigones no-sellados. La Figura 2 muestra algunos resultados obtenidos en pastas de cemento no-selladas tomadas de referencias $(2,3,5,18)$. A los 7 días para relaciones a/c entre 0,40 y 0,80 la retracción volumétrica debido a la retracción química interna alcanza valores entre $\in C=3,5$ y $5,5 \mathrm{~cm}^{3} / 100 \mathrm{~g} \mathrm{C}$. Después de 1 día las contracciones alcanzan a un $40 \%$ a $60 \%$ del valor a los 7 días.

En probetas selladas, la retracción volumétrica depende de la rigidez de la matriz. Para relaciones a/c altas, la porosidad del gel de HSC (Hidratos de Silicato de Calcio) aumenta, resultando una menor interacción entre las partículas de HSC. Por lo tanto se desarrolla una matriz débil, la cual podrá contraerse más, debido a la acción de fuerzas internas. Este comportamiento fue verificado por de Haas et al (19) en pastas de cemento a edades mayores que 10 horas. En las 10 primeras horas observó él un comportamiento inverso, el cual se atribuyó a variaciones en la morfología de la ettringita formada. La Figura 3 muestra resultados de mediciones obtenidas en probetas selladas (7 pastas de cemento y 1 mortero) tomados de referencias $(5,7,19)$. La mayoría de las investigaciones se prolongan sólo hasta cerca de 1 día. Como era de esperar, las mayores contracciones se observan en las mezclas con relaciones a/c altas.

2) La retracción química ocurre solamente en el cemento y no está influida por la adición de áridos. Los áridos disminuyen el contenido de cemento en la mezcla susceptible de retraer, lo que significa una reducción indirecta de la retracción química total. No obstante en probetas that deformations which take place in the first few hours before demoulding normally are not comprehended. Recently Komlos (14) was able to make the first measurement just after placing ( 8 min) with an uniaxial dilatometer, but he did not measure volumetrically to enable a comparison. Brameshuber (16) was able to compare the results of both methods by considering only the volume change occured after the uniaxial measurement was started.

\section{Influences on the Measurement of Chemical Shrinkage}

1) The amount of water, defined by the w/c-ratio, is one of the most important factors for the formation and morphologie of the hydration products and also the porosity of the paste.

In unsealed specimens with a high w/c-ratio a convenient water transport permitts a more exact measurement of the internal chemical shrinkage. This principle was used by Jung (17) in the 70ies to measure the chemical shrinkage in unsealed concretes. Some results on unsealed cement pastes taken from Ref. $(2,3,5,18)$ are shown in Figure 2. For w/c-ratios between 0.40 and 0.80 the volume contractions after 7 days due to internal chemical shrinkage reach values between $\in C=3.5$ and $5.5 \mathrm{~cm}^{3} / 100 \mathrm{~g} \mathrm{C}$. After 1 day the contraction is about $40 \%$ to $60 \%$ of the 7 days values.

For sealed specimens the volume contraction depends on the rigidity of the matrix formed. At high w/c-ratios the porosity of the $\mathrm{CSH}$-gel increases resulting in a lower interaction between the CSH particles. Thus a weaker system develops which can contract more owing to the action of internal forces. This behaviour was confirmed by the investigations of de Haas et al (19) for cement pastes after an age of 10 hours. Before an age of 10 hours an inverse behaviour was observed which can be attributed to variations in the morphology of the ettringite. Figure 3 shows the results of measurements on sealed samples ( 7 cement pastes and 1 mortar) taken from references $(5,7,19)$. Most investigations study only the behaviour up to 1 day. As expected the larger contractions are observed for higher w/c-ratios.

2) The chemical shrinkage takes place only in cement and is not directly influenced by the addition of aggregates. The aggregates merely reduce the cement content able to shrink, which means a indirect reduction of the total chemical shrinkage. However, for sealed specimens a 


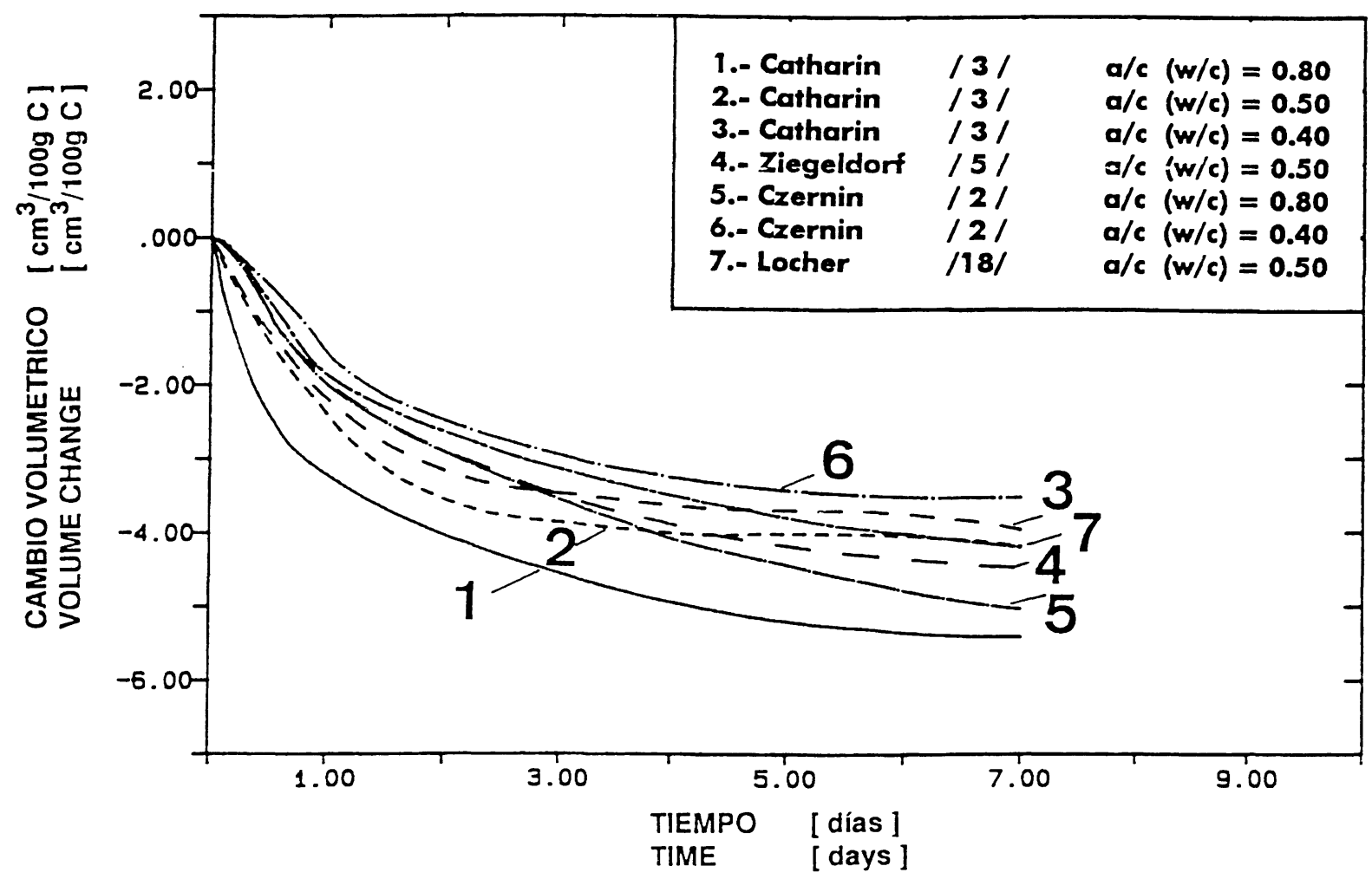

Fig. 2.-Retracción química interna en pastas de cemento no-selladas según literatura.

Fig. 2.-Internal chemical shrinkage of unsealed cement pastes taken from the literature.

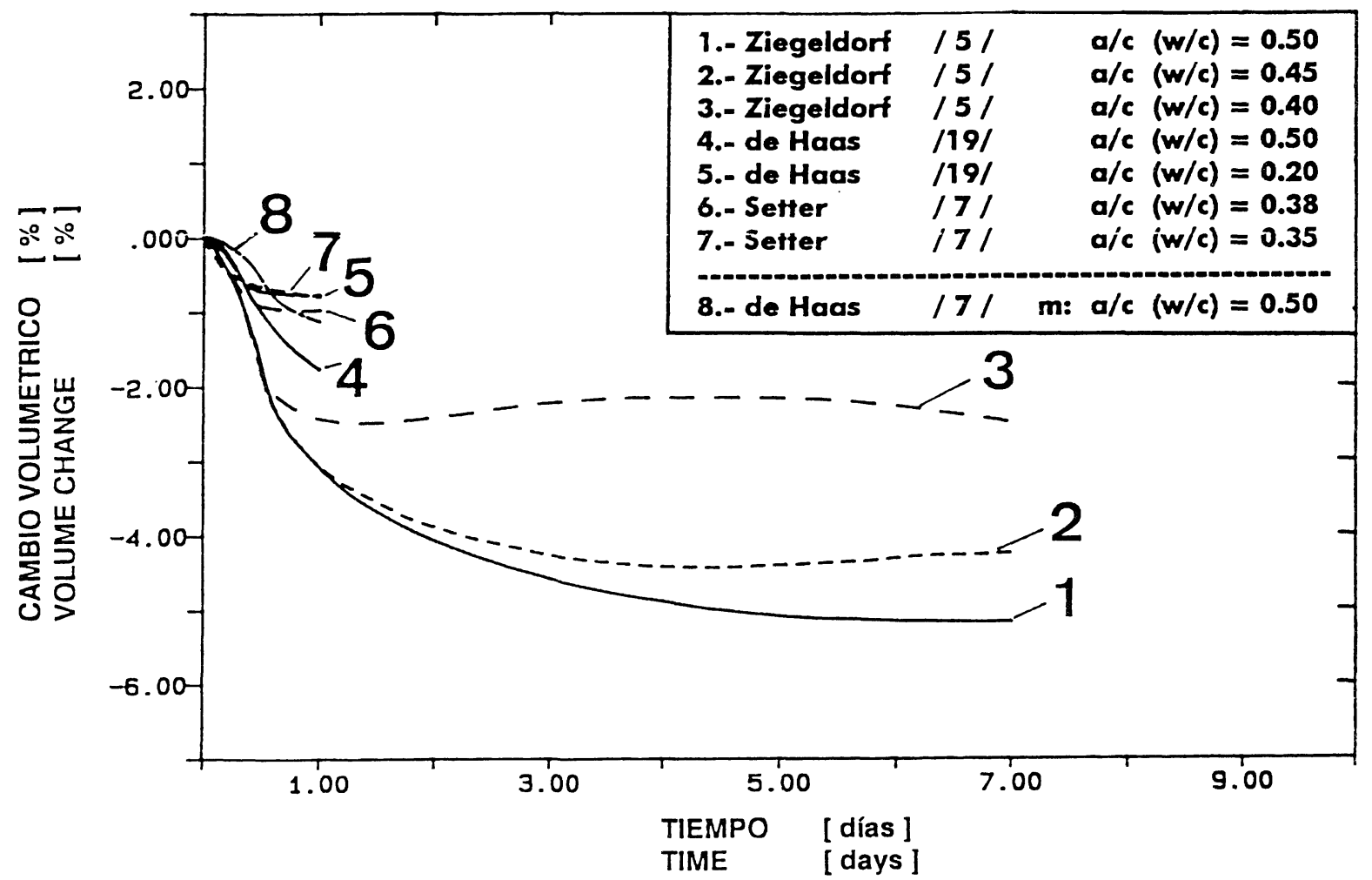

Fig. 3.-Retracción química volumétrica en pastas de cemento y un mortero sellado según literatura.

Fig. 3.-Bulk chemical shrinkage of sealed cement pastes and one mortar taken from the literature. 
selladas se espera además un efecto de restricción. En las mediciones de Haas (19), se confirmó una menor retracción de los morteros (Fig. 3 curvas 8 y 4). Por otro lado los resultados de Detriche (20) muestran que la adición de áridos siempre reduce la primera y segunda retracción, mostrando la primera retracción un máximo para cierta proporción de áridos. En hormigones se espera que la retracción química tenga sólo un efecto muy reducido en las dimensiones de una probeta, debido a que la proporción de cemento es reducida drásticamente y a que los áridos resisten las contracciones (3).

3) La medición en probetas no-selladas no es afectada por la exudación. Sin embargo en el caso de probetas selladas este agua será nuevamente absorbida interfiriendo en la medición volumétrica, y será medida como parte de la retracción química volumétrica, cuando en realidad representa parte de la retracción química interna. Al remover Setter (7) después de 2 horas el agua debido a la exudación en pastas de cemento con una relación $\mathrm{a} / \mathrm{c}=0,38$ obtuvo una disminución volumétrica aprox. $40 \%$ menor. Para relaciones a/c mayores se espera una desviación aún mayor.

4) Mediante mediciones volumétricas Ziegeldorf (5) estudió el efecto del tamaño de la probeta. Las probetas más voluminosas mostraron una mayor retracción. El explicó este comportamiento mediante la cantidad de agua exudada, la cual es superior en las probetas de mayor volumen. Por otro lado, el tamaño de la probeta influye fuertemente en las mediciones de cambios de longitud. Probetas más largas muestran valores menores de retracción debido al roce superficial entre la probeta y el molde (15).

\section{DESARROLLO EXPERIMENTAL}

\section{Equipo de medida}

En condiciones prácticas la retracción química ocurre al mismo tiempo que la evaporación. Por lo tanto la medición en probetas no-selladas curadas en aire no permiten la separación de ambos fenómenos. En cambio, el sellado de la probeta sí permite una separación, pero lamentablemente no representa la situación práctica, pues permite el desarrollo total de presiones negativas debido a la autodesecación. Aunque resultan mayores retracciones químicas, son posibles de comparar entre sí los resultados. Tomando esta situación en consideración se realizaron con un volumenómetro (Fig. 4) medidas en probetas selladas y no-selladas.

Las probetas fueron puestas en el volumenómetro y sumergidas bajo agua, asegurándose luego la tapa con tornillos. Para asegurar el sellado del sistema se usó una grasa de silicona. Los restraining effect of the aggregates is expected as well. In the measurements of de Haas (19) the lower shrinkage of mortar was confirmed (compare curves 8 and 4 in Fig. 3). Detriche (20) also found that the addition of aggegates always reduces the first and second shrinkage whereas the first shrinkage showed a maximum for a certain grain proportion. For concretes it is expected that the chemical shrinkage has only a negligible effect on sample volume, because the cement content is reduced considerably and also the aggregates resist the contractions (3).

3) Bleeding does not affect the measurements on unsealed specimens. However, for sealed specimens this water will be sucked back influencing the volume measurement. It will be measured as a part of the bulk chemical shrinkage although it represents a part of the internal shrinkage. Setter (7) studied this effect in cement pastes with $w / c=0.38$ by removing the bleeding water 2 hours after mixing. He obtained an about $40 \%$ lower final volume contraction. For higher w/c-ratios a higher deviation is expected.

4) On sealed volumetrical experiments Ziegeldorf (5) studied the effect of the size of specimen. Larger specimens showed larger shrinkage. He explained this behaviour by the different amount of bleeding water which is increased on larger specimens. On the other hand the size of specimen influences strongly the length change measurements. Larger specimens show lower chemical shrinkage due to friction between the sample and the mould (15).

\section{EXPERIMENTAL}

\section{Apparatus}

Under practical conditions chemical shrinkage occurs at the same time as evaporation. Therefore the measurement of unsealed specimens cured at air does not permit the separation of both effects. On the other hand the sealing of the specimen allows separation, but unfortunately does not represent the practical situation because negative pressures due to selfdesiccation are allowed to develop completely. Although this leads to higher chemical shrinkage, the comparison of results is allowed. Taking this into account sealed and unsealed specimens were tested in a volumenometer (Fig. 4).

The specimens were placed under water in the volumenometer and the lid was secured with screws. Silicone grease was used to render the system water-tight. Volume changes were 


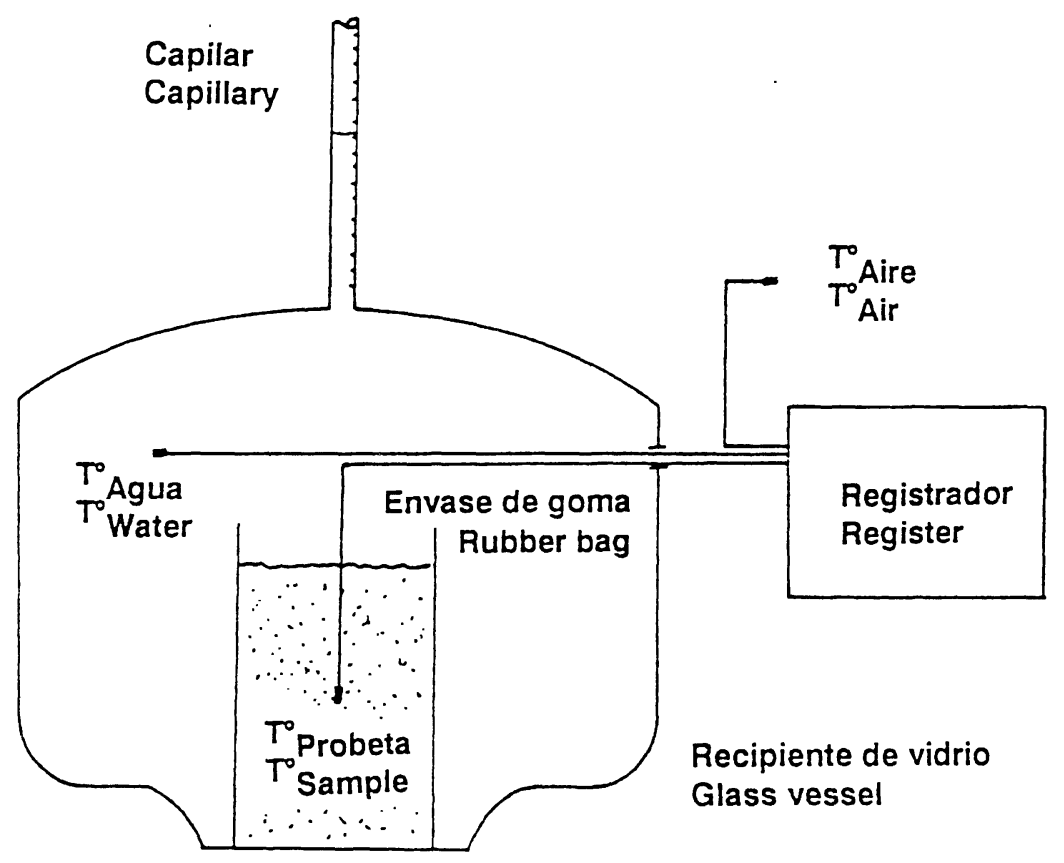

Fig. 4.- Volumenómetro para medir cambios volumétricos a edad temprana.

Fig. 4.-Volumenometer for measuring volume changes at early ages.

cambios volumétricos se midieron en un tubo capilar de $50 \mathrm{ml}$. montado en la parte superior del recipiente y graduado cada $0,1 \mathrm{ml}$. La temperatura del agua y de la probeta se midió con 2 termorresistencias tipo Pt-100. El equipo fue instalado a una temperatura de $20^{\circ} \mathrm{C}$ y una humedad relativa del $65 \%$.

La medición de probetas selladas es más difícil de realizar que la de probetas no-selladas. La probeta debe estar de tal modo sellada, que el agua externa no pueda infiltrarse. Además, la probeta debe estar libre de burbujas de aire que podrían interferir en la medición, y la membrana de sellado debe poder seguir las contracciones volumétricas. Por consiguiente, se seleccionó un envase de goma impermeable $(2.000 \mathrm{cc})$ lo suficientemente grueso para resistir las irregularidades de la superficie del hormigón. La probeta se selló en su parte superior con una tapa plástica con un agujero central que permite el escape de burbujas de aire formadas durante la vibración. Luego el agujero fue cerrado con un corcho y sellado con silicona.

\section{Preparación del ensayo}

Los áridos y el cemento fueron mezclados durante 1 min en seco en una mezcladora mecánica de tipo vertical. Después de agregar el agua a una temperatura adecuada, con tal de obtener la temperatura inicial de $20^{\circ} \mathrm{C}$, se volvió a mezclar durante otros $2 \mathrm{~min}$. La mezcla fue measured with a $50 \mathrm{ml}$ capillary graduated in $0.1 \mathrm{ml}$ mounted on the top. The temperatures of the water and the sample were recorded with two Pt-100 resistance thermometers. The volumenometer was stored at $20^{\circ} \mathrm{C}$ and a relative humidity of $65 \%$.

Testing of sealed specimens is more complicated than that of unsealed. The specimen had to be sealed so that no water could infiltrate. Furthermore, the specimen must be free from air bubbles which would interfere with the measurement and the sealing membrane must be able to follow the volume contraction. Therefore a water-tight rubber bag (2.000 cc.) was used which was strong enough not to be punctured by irregularities in the concrete surface. The specimen was sealed by covering the top of the specimen with a plastic lid which had a central hole that allowed air bubbles formed during vibration to escape. Later on it was closed with a cork and sealed with silicone grease.

\section{Measurement Procedure}

The aggregates were mixed dry with the cement in a drum mixer. Water then was added with an appropiate temperature so that an initial temperature of the fresh mix of $20^{\circ} \mathrm{C}$ was obtained. The mixing time was 2 min. The mix was poured into the rubber bag, vibrated for $45 \mathrm{~s}$ 
introducida al envase, sometida a vibración durante $45 \mathrm{seg}$ e inmediatamente pesada y colocada en el recipiente. Si se trataba de una medición de una probeta sellada se continuaba con el procedimiento descrito anteriormente. Luego el envase fue colocado en el recipiente y el volumenómetro llenado con agua. Después de haberlo tapado e instalado el tubo capilar, se realizó la primera lectura aprox. a los $30 \mathrm{~min}$ después de haber preparado la mezcla.

Todas las mediciones se realizaron hasta una edad de 7 días. Al final del ensayo, mediante el control del peso de la probeta y del estado de su superficie, se verificó la impermeabilidad de cada probeta sellada. En el caso de encontrarse una superficie mojada, el ensayo se repitió.

\section{Calibración y precisión}

La medición de 2 hormigones idénticos en condiciones no-selladas mostró una buena reproducibilidad; a los 7 días la diferencia entre los 2 ensayos fue menor que $0,4 \mathrm{~cm}^{3} / 100 \mathrm{~g} \mathrm{C}$, 10 que representa aprox. un $8 \%$ del valor final (Fig. 5). Tras un aumento constante de la retracción en los primeros días, la retracción química tiende a estabilizarse lentamente. Debido al calor de hidratación, la probeta aumenta su and immediatelly weighed. If a sealed specimen was tested it was proceeded according to the previously described procedure. Then the bag was placed into the vessel and the volumenometer was filled with water. At last the capillary was installed and the first measurement was made already 30 min after the adding water.

All measurements were carried out up to an age of 7 days. Then the tightness of the sealed samples was checked by weighing the samples and inspecting the sample surface. If the surface was wet the measurement was repeated.

\section{Calibration and Accuracy}

The measurement of two identical unsealed concrete specimens showed a well reproducibility; after 7 days the difference between the two tests was lower than $0.4 \mathrm{~cm}^{3} / 100 \mathrm{~g} \mathrm{C}$, representing an error of about $8 \%$ (see Fig. 5). After increasing constantly during the first few days, the chemical shrinkage stabilized slowly. Due to the heat of hydration the sample warmed up by about $2 K$ causing a temperature rise in the surrounding

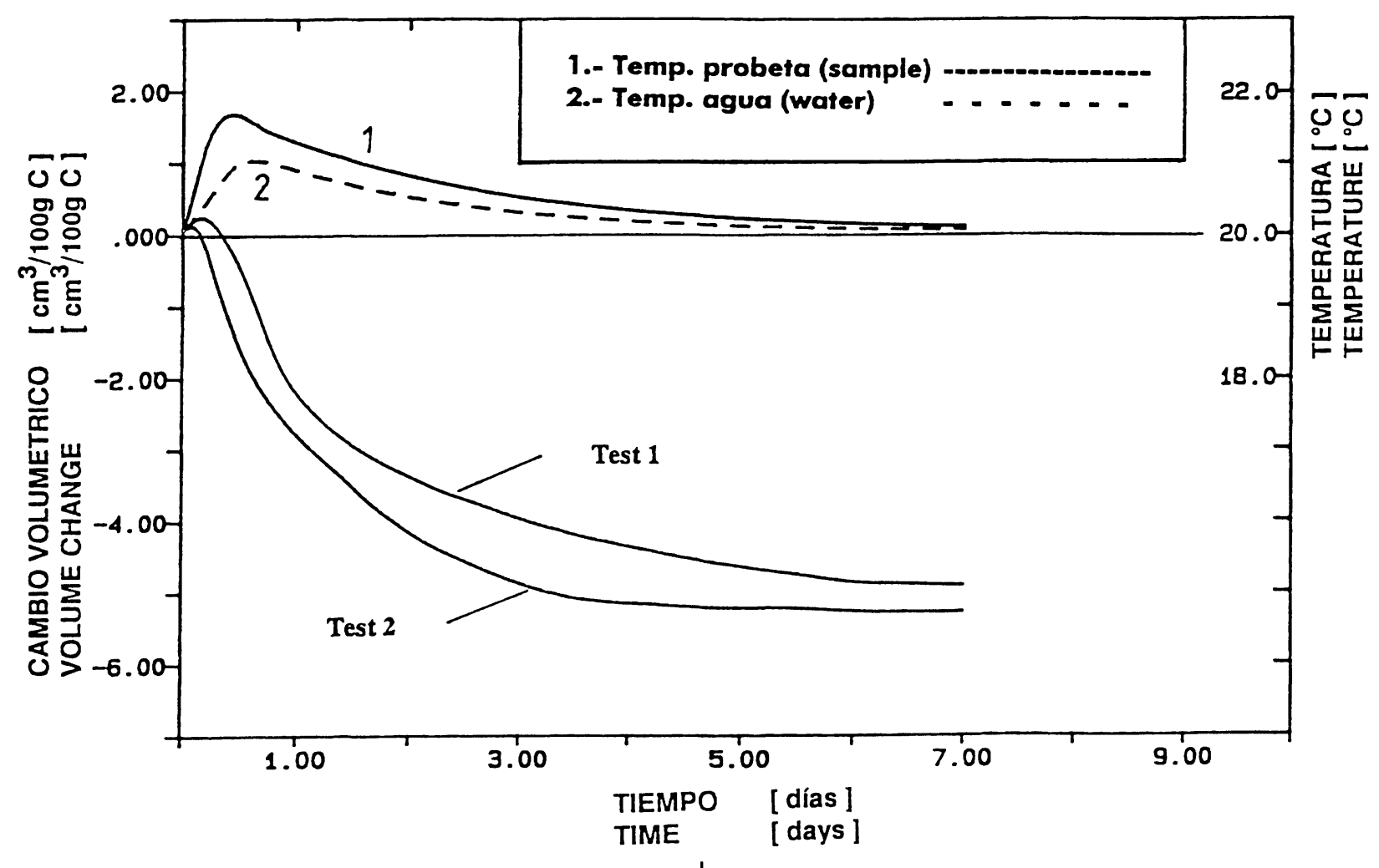

Fig. 5.-Reproducibilidad del ensayo (hormigones no-sellados) con desarrollo típico de temperaturas.

Fig. 5.-Reproducibility of the measurement (unsealed concretes) with typical temperature development. 
temperatura en cerca $2 \mathrm{~K}$, induciendo a un aumento de la temperatura del agua del volumenómetro en $1 \mathrm{~K}$ (Fig. 5). A los 7 días ambas temperaturas alcanzan un valor constante.

El aumento de temperatura produce una expansión térmica de la probeta con una consecuente reducción de los valores de retracción medidos. Esta influencia no ha sido considerada, dado que estos cambios volumétricos son de poca magnitud $\theta$ interfieren sólo en las primeras horas, período en el cual se alcanza la temperatura máxima de hidratación.

\section{Materiales y programa de trabajo}

Fueron usados los siguientes materiales:

- Árido cuarcítico < $16 \mathrm{~mm}$.

- Arena normalizada según DIN 1164.

- Cemento PZ-35F tipo Portland con una finura $3.100 \mathrm{~cm}^{2} / \mathrm{g}$

- Aditivo expansivo, en base a la formación de ettringita (sulfoaluminato de calcio CSA).

La influencia de la relación cemento/árido fue estudiada en probetas selladas y no-selladas. Para ello se ensayaron 2 pastas de cemento, 1 mortero y 3 hormigones, cuyas dosificaciones se muestran en Tabla 1. El mortero fue confeccionado con arena normalizada según water of about $1 \mathrm{~K}$ (Fig. 5). After 7 days both temperatures reached a constant value.

The temperature increase caused a thermal expansion of the sample, resulting in a reduction of the measured shrinkage. This influence has not been taken into account because these volume changes were very small and affected the measurement only during the first few hours up to the reaching of the maximum temperature.

\section{Materials and Testing Programme}

Following materials were used:

- Quartz coarse aggregate < $16 \mathrm{~mm}$.

- Standard sand acc. DIN 1164.

- Ordinary Portland cement (PZ 35F) with a fineness of $3100 \mathrm{~cm}^{2} / \mathrm{g}$.

- CSA Expansive additive (calcium sulphoaluminate), based on ettringite formation.

The influence of cement/aggregate ratio was investigated on sealed and unsealed specimens. For this purpose two cement pastes, one mortar and three concretes were tested. The mix compositions of those are compiled in Table 1. Mortar was made according to DIN 1164 (21).

TABLA 1 TABLE 1

Dosificación con respecto al peso del cemento, contenido de cemento en volumen y variación volumétrica a los 7 días

(Mix composition in terms of cement weight, volumetrical cement content and volume changes after 7 days)

\begin{tabular}{|c|c|c|c|c|c|c|c|c|c|}
\hline \multirow{3}{*}{$\begin{array}{l}\text { Probeta } \\
\text { Sample }\end{array}$} & \multicolumn{4}{|c|}{$\begin{array}{l}\text { DOSIFICACION } \\
\text { MIXCOMPOSITION }\end{array}$} & & \multicolumn{4}{|c|}{$\begin{array}{c}\text { VARIACION VOLUMETRICA } \\
\text { VOLUME CHANGE }\end{array}$} \\
\hline & \multirow[t]{2}{*}{$\begin{array}{l}\text { Cemento } \\
\text { Cement }\end{array}$} & \multirow[t]{2}{*}{$\begin{array}{l}\text { Agregados } \\
\text { Aggregate }\end{array}$} & \multirow[t]{2}{*}{$\begin{array}{l}\text { Agua } \\
\text { Water }\end{array}$} & \multirow[t]{2}{*}{$\begin{array}{l}\text { Aditivos } \\
\text { Additives }\end{array}$} & \multirow[t]{2}{*}{$V_{\text {Cem }} / V_{\text {Tot }}$} & \multicolumn{2}{|c|}{$\begin{array}{l}\text { no-sellado } \\
\text { unsealed }\end{array}$} & \multicolumn{2}{|c|}{$\begin{array}{l}\text { sellado } \\
\text { sealed }\end{array}$} \\
\hline & & & & & & Ev & Ec & Ev & Ec \\
\hline $\begin{array}{l}\text { Pasta } 1 \\
\text { Cement paste } 1\end{array}$ & 1.00 & - & 0.35 & - & 0.48 & 5.05 & 3.40 & 2.85 & 1.92 \\
\hline $\begin{array}{l}\text { Pasta } 2 \\
\text { Cement paste } 2\end{array}$ & 1.00 & - & 0.50 & - & 0.39 & 5.24 & 4.31 & 3.61 & 2,97 \\
\hline $\begin{array}{l}\text { Mortero } \\
\text { Mortar }\end{array}$ & 1.00 & 1.00 & 0.50 & - & 0.27 & 3.63 & 4.37 & 2.75 & 3,31 \\
\hline $\begin{array}{l}\text { Hormigón } 1 \\
\text { Concrete } 1\end{array}$ & 1.00 & 5.31 & 0.60 & - & 0.11 & 1.40 & 4.25 & 0.58 & 1,70 \\
\hline $\begin{array}{l}\text { Hormigón } 2 \\
\text { Concrete } 2\end{array}$ & 0.90 & 5.17 & $0.60^{\circ} 1$ & 0.10 CSA & 0.11 & - & - & 1.16 & - \\
\hline$\underset{\text { Concrete } 3}{\text { Hormigón } 3}$ & 0.85 & 5.31 & $0.60^{\circ} 1$ & 0.15 CSA & 0.11 & - & - & -2.50 & - \\
\hline
\end{tabular}

(*1) $a / c$ referido al contenido de aglomerante (cemento + CSA) $\in V=($ Vol. \%).

(*1) $w / c$ refered to the binder content (cement + CSA $) \in C=\left(\mathrm{cm}^{3} / 100 \mathrm{~g} \mathrm{C}\right)$. 
DIN 1164 (21). La mezcla standard de hormigón contenía $340 \mathrm{~kg} / \mathrm{m}^{3}$ de cemento con una relación $a / c=0,60$. La influencia del aditivo expansivo en la retracción química volumétrica fue estudiada reemplazando un $10 \%$ y $15 \%$ del cemento por el aditivo.

\section{RESULTADOS Y DISCUSIÓN}

Los cambios volumétricos medidos después de 7 días se encuentran en la Tabla 1.

En la Figura 6 se muestra la retracción química interna en probetas no-selladas (agua absorbida). El aumento de la cantidad de áridos se manifiesta a los 7 días con una reducción de la retracción química desde $\in V=5,2 \%$ para pasta $a \in V=3,6 \% y \in V=1,4 \%$ para mortero $y$ hormigón respectivamente. Para el hormigón sin aditivo expansivo se observó en las primeras horas una leve fase de hinchamiento.

Al referir la retracción química interna al contenido de cemento (Fig. 7), se puede observar que a los 7 días todas las probetas no-selladas alcanzaron aprox. el valor final de $\in \mathrm{C}=4,3 \mathrm{~cm}^{3} / 100 \mathrm{~g} \mathrm{C}$. La menor retracción de la pasta 1 con una relación $a / c=0,35$ es causada probablemente por la presencia de cemento sin hidratar. Mientras la permeabilidad de la pasta endurecida permita un transporte expedito del agua dentro de la pasta, normalmente para relaciones $a / c$ mayores que 0,40 , la retracción química interna (considerando $\epsilon c)$ es independiente de la relación a/c y de la presencia de áridos. La mayor cantidad de agua para relaciones a/c mayores que 0,40 se manifiesta solamente en la rapidez de la retracción química. Los resultados concuerdan con los valores medios mostrados en Figura 2, y como se esperaba, los mayores cambios volumétricos ocurren dentro de las primeras 24 horas.

La Figura 8 muestra el desarrollo de la retracción química volumétrica en probetas selladas, incluyendo a ambos hormigones con aditivo expansivo. A los 7 días se midió una retracción química volumétrica de $\in V=3,6 \%$ para pasta de cemento, $\in \mathrm{V}=2,7 \%$ para mortero $y \in V=0,6 \%$ para hormigón sin aditivos. Si estos cambios volumétricos son referidos al contenido de cemento $(\in C)$ se puede constatar otra diferencia entre la pasta de cemento y hormigón (ver Tabla 1) mientras que en la pasta de cemento con una relación $\mathrm{a} / \mathrm{c}=0,50$ se determinó un valor aprox. de $\in \mathrm{C}=3,0 \mathrm{~cm}^{3} / 100 \mathrm{~g} \mathrm{C}$, en el hormigón este valor fue sólo de $\in \mathrm{C}=1,7 \mathrm{~cm}^{3} / 100 \mathrm{~g} \mathrm{C}$. Es posible entonces concluir, que en hormigones sellados la retracción química está influida tanto por el contenido de cemento como por el árido grueso que restringe la deformación. Así es, que sólo una pequeña parte de la retracción química lleva a una reducción de las dimensiones externas.
The standard concrete mix contains $340 \mathrm{~kg} / \mathrm{m}^{3}$ cement with $w / c=0.60$. The influence of expansive additive on bulk chemical shrinkage was tested by replacing $10 \%$ and $15 \%$ of cement by the expansive additive.

\section{RESULTS AND DISCUSSION}

The volume changes measured after 7 days are summarized in Table 1.

In Figure 6 the internal chemical shrinkage on unsealed specimens (absorbed water) is shown. Increased quantity of aggregates led to a reduction of the chemical shrinkage after 7 days from $\in V=5.2 \%$ for cement paste to $\in V=3.6 \%$ and $\in V=1.4 \%$ for mortar and concrete respectively. For the concrete without expansive additive a slight swelling was observed during the first few hours.

On relating the internal chemical shrinkage of the samples to the cement content (Fig. 7) it can be seen that after 7 days all unsealed samples reached nearly the same final value of about $\in C=$ $4.3 \mathrm{~cm}^{3} / 100 \mathrm{~g} \mathrm{C}$. The somewhat smaller shrinkage of cement paste 1 with $w / c=0,35$ is probably caused by the presence of unhydrated cement. While the permeability of the hardened paste allows the transport of water into the paste, the internal chemical shrinkage (considering $\in c$ ) for $w / c$-ratios above 0.40 is independent of the $w / c$-ratio and aggregate content. The increased quantity of water at w/c-ratios above 0.40 only influences the speed of the chemical shrinkage. The results agree with the mean values in Figure 2 , and as expected, the main volume changes occur within the first 24 hours.

Figure 8 shows the development of the bulk chemical shrinkage for sealed samples including both concretes with expansive additive. After 7 days a bulk chemical shrinkage of $\in V=3.6 \%$ was measured for cement paste, $\in V=2.7 \%$ for mortar and $\in V=0.6 \%$ for concrete without additive. When these volume changes are related to the cement content $(\epsilon c)$, differences between cement paste and concrete could be established (compare Table 1): while for the cement paste with $w / c=0.50$ a value of about $\in C=3.0 \mathrm{~cm}^{3} / 100$ $g C$ was determined, for concrete only $\in C=1.7$ $\mathrm{cm}^{3} / 100 \mathrm{~g} C$ was measured. Thus it can be assumed that in sealed concretes the chemical shrinkage is influenced as well as by the content of cement paste as also by the restraining effect of the coarse aggregate. So only a small part of chemical shrinkage leads to a reduction of the external dimensions. 


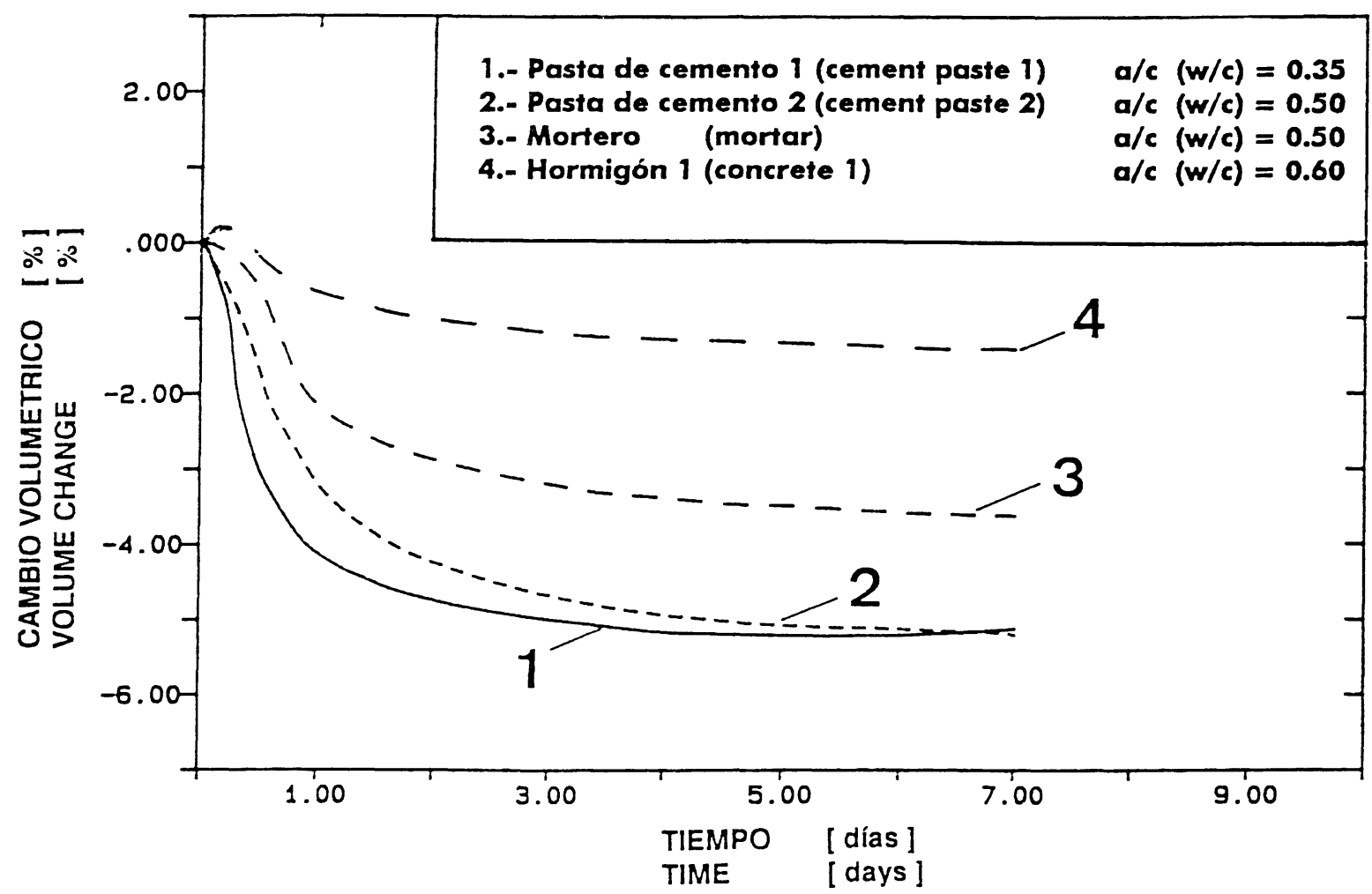

Fig. 6.-Retracción química interna en probetas no-selladas referida al volumen inicial.

Fig. 6. - Internal chemical shrinkage of unsealed specimens in terms of the initial volume.

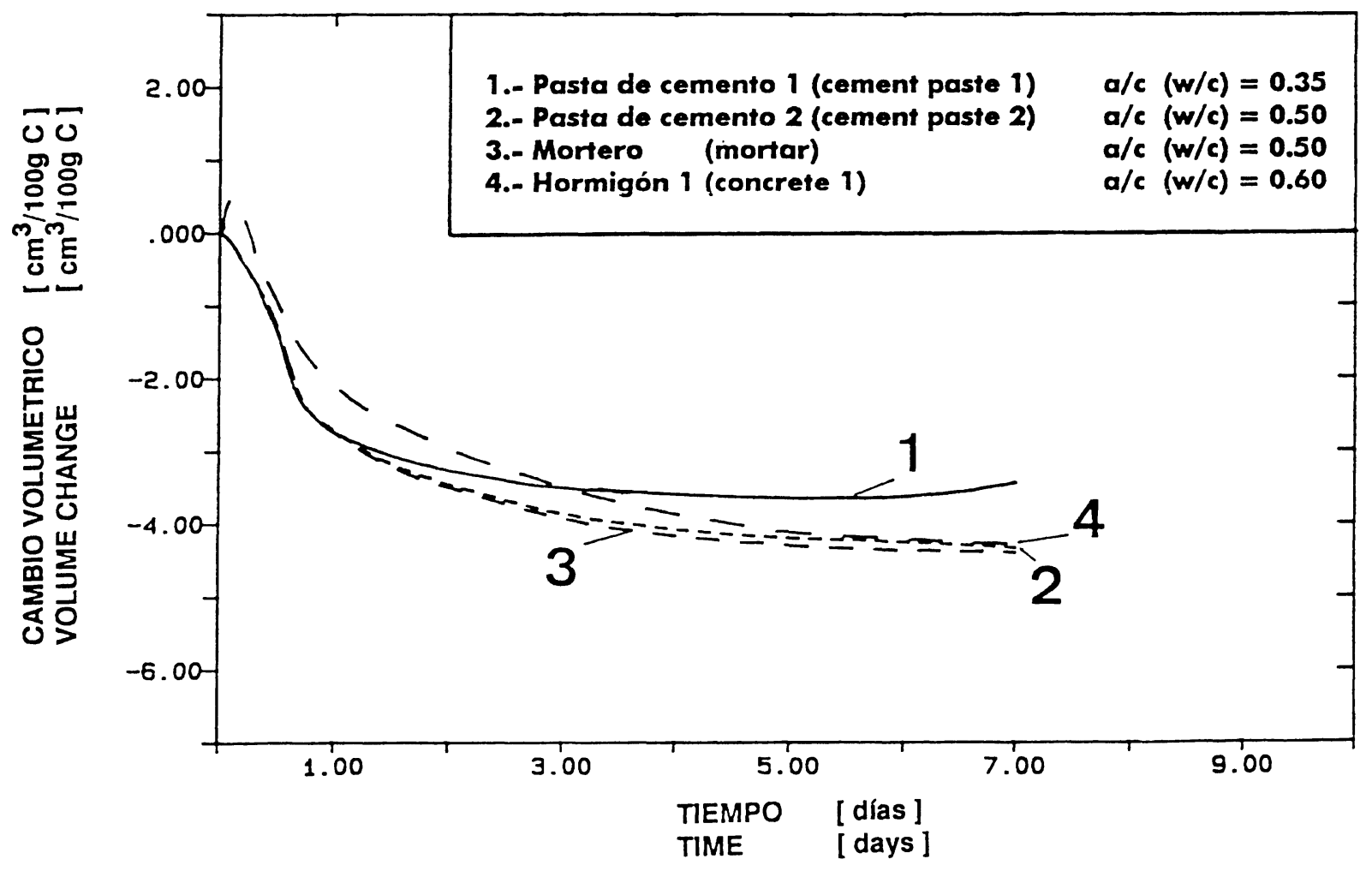

Fig. 7.-Retracción química interna en probetas no-selladas referida al contenido de cemento

Fig. 7.-Internal chemical shrinkage of unsealed specimens in terms of the cement content. 


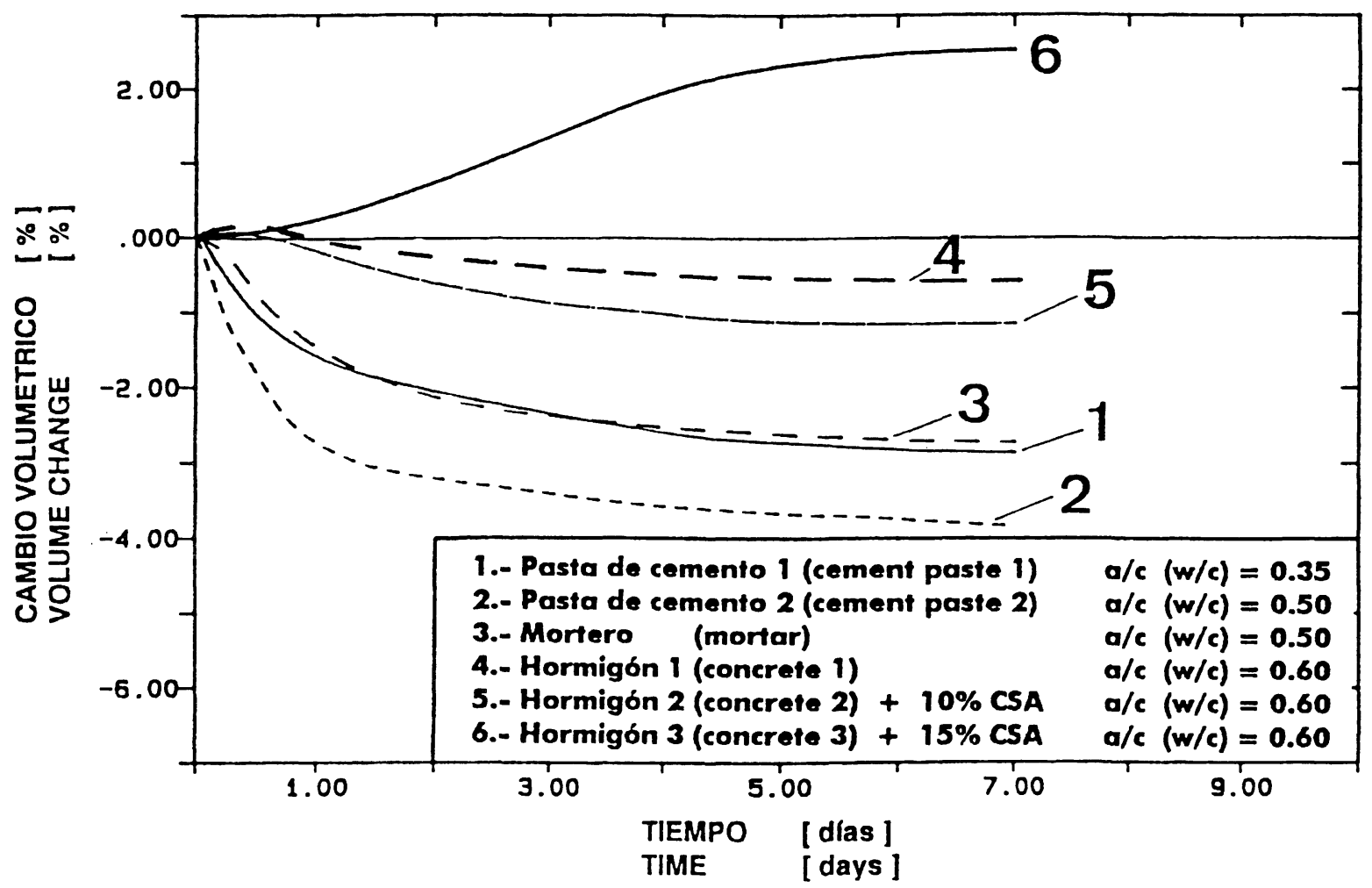

Fig. 8.-Retracción química volumétrica en probetas selladas referida al volumen inicial.

Fig. 8.-Bulk chemical shrinkage of sealed specimens in terms of the initial volume.

La adición de un $10 \%$ de aditivo expansivo no mostró la expansión esperada. Incluso la retracción química aumentó desde $\in \mathrm{V}=0,6 \%$ a $1,2 \%$. Esto significa que el efecto expansivo no fue lo suficiente como para compensar la mayor retracción debido a la mayor cantidad de ettringita formada a partir del CSA. En ensayos volumétricos con cementos expansivos Kühl (22) ya había observado en estos cementos una retracción final en vez de una expansión. En cambio, el hormigón con un $15 \%$ de aditivo expansivo mostró un comportamiento bastante diferente. Desde un principio el efecto expansivo llevó a un aumento de volumen, el cual alcanzó a un 2,5\%. No obstante, una expansión de esta magnitud, bajo ciertas circunstancias, puede llegar a causar grandes daños al hormigón (23).

Los cambios volumétricos de las probetas noselladas y de las probetas selladas sin aditivo expansivo son comparados en la Figura 9, en función del contenido de cemento (\% en volumen). Para ambos casos la retracción química disminuye cuando el contenido de cemento es reducido. En todos los casos el sellado de la probeta redujo el cambio volumétrico (retracción química volumétrica).

La comparación entre los cambios volumétricos de una pasta no-sellada y un hormigón sellado mostró que la retracción química volumétrica del hormigón alcanza aprox. sólo a un $10 \%$ de la
The addition of a $10 \%$ expansive additive did not lead to an expansion as expected. The chemical shrinkage was even increased from $\in V=0.6 \%$ to $1.2 \%$. This means, that the expansive effect was not high enough to compensate the higher shrinkage due to the higher quantity of ettringite formed by the CSA particles. Similar behaviour was observed on volumetrical measurements on expansive cements by Kühl (22), who measured a final shrinkage instead of an expansion. In opposite to this the concrete with $15 \%$ expansive additive showed a quite different behaviour. From the very beginning the expansive reaction led to a volume increase. After 7 days an expansion of $\in V=2.5 \%$ was obtained. However, such a large expansion already can cause under certain circumstances damaging (23).

The volume change of unsealed and sealed specimens without expansive additive is compared in Figure 9 as a function of the volumetric cement content. For both cases the chemical shrinkage decreased when the content of cement paste was reduced. In all cases sealing of the specimens reduced the volume change (bulk chemical shrinkage).

The comparison between the volume changes of unsealed cement pastes and sealed concrete showed that the bulk chemical shrinkage of concrete reached roughly $10 \%$ of the internal 


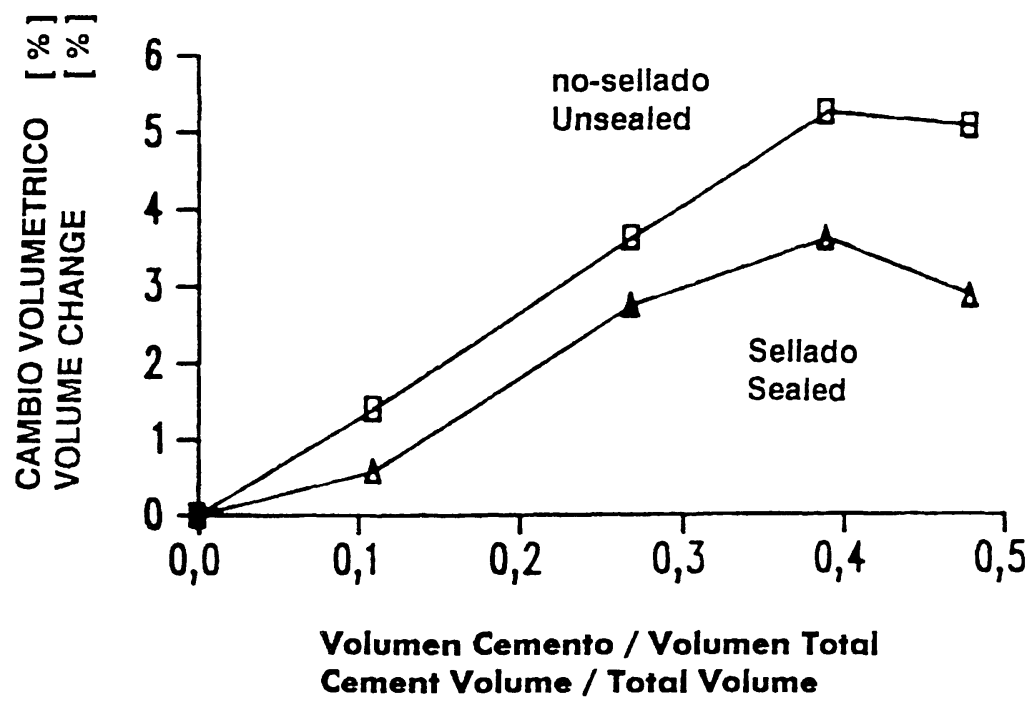

Fig. 9.-Comparación de los cambios volumétricos entre probetas selladas y no-selladas a los 7 días.

Fig. 9. - Comparison of the volume changes between sealed and unsealed samples after 7 days.

retracción química interna de la pasta. Esto coincide con valores publicados en la referencia (2). Asumiendo un material homogéneo, el cambio volumétrico del hormigón $\in V=0,6 \%$ correspondería a una deformación lineal aprox. de $2.000 \mu \mathrm{s}$, la cual a su vez implica una diferencia de temperatura cercana a $200 \mathrm{~K}$. Comparado con un hormigón con curado normal, el cual se calienta debido al calor de hidratación entre 20 a $30 \mathrm{~K}$, representa esto una deformación 7 a 10 veces superior, la cual jamás se espera ocurra en un hormigón. Esto muestra claramente que la medida de la retracción química da un valor de cambio volumétrico mucho mayor que el que se espera ocurra en la realidad.

\section{CONCLUSIONES}

El efecto de la retracción química durante la hidratación fue determinada en probetas selladas (retracción química interna) y no-selladas (retracción química volumétrica) sumergidas bajo agua. De este estudio se han obtenido las siguientes conclusiones:

- La diferenciación entre probetas selladas y noselladas es muy importante. En el caso de probetas no-selladas se mide el volumen de agua que ha sido absorbida en la pasta de cemento medido. De este modo las dimensiones externas no cambian. Por otro lado cuando la probeta es sellada, el agua no puede ser absorbida, desarrollándose una autodesecación interna que junto al desarrollo de presiones negativas genera fuerzas internas. Entonces la probeta se retrae, midiéndose su variación volumétrica real. Se chemical shrinkage of cement paste. This agrees with values published in reference (2). Assuming a homogeneous material the volume change of concrete $\in V=0,6 \%$ correlates with a linear deformation of about $\in I=2.000 \mu \mathrm{s}$. This, however, corresponds with a temperature difference of about $200 \mathrm{~K}$. Compared with a normally cured concrete, which warms up due to heat of hydration by only 20 to $30 \mathrm{~K}$, this represents a 7 to 10 times higher deformation, never to be expected in concrete. This shows clearly that the measurement of chemical shrinkage gives a much higher volume change than that which can be expected in reality.

\section{CONCLUSIONS}

The effect of chemical shrinkage during hydration was determined on unsealed (internal chemical shrinkage) and sealed (bulk chemical shrinkage) specimens submerged under water. The following conclusions can be made from this study.

- The differentiation between unsealed and sealed specimens is very important. In the case of unsealed specimens water can be sucked into the cement paste and the volume of this absorbed water is measured. Thereby the external dimensions are not changed. On the other hand when the specimen is sealed, water cannot be absorbed and internal selfdesiccation together with a development of negative pressures cause internal forces. Thus the specimen shrinks and a real volume contraction is measured. It should be 
debe mencionar, que en este caso la retracción volumétrica es sobreestimada, dado que en condiciones prácticas siempre ocurre hasta cierto grado un equilibrio de las presiones desarrolladas.

- En probetas no-selladas con una relación a/c $>0,40$, se encontró que la cantidad de agua absorbida por unidad de cemento fue siempre la misma, independientemente del tipo de mezcla. Esto significa que la retracción química está influida sólo por el contenido de pasta de cemento. Si el contenido de cemento es reducido debido a la presencia de áridos, el cambio volumétrico se reduce proporcionalmente.

- En probetas selladas el cambio volumétrico depende del efecto de la retracción química en el interior de la probeta. La retracción química volumétrica siempre es menor que la retracción química interna. La influencia de distintos factores, como la relación a/c, exudación, áridos y otros, dificultan la interpretación de los resultados. Sin embargo, el efecto de restricción del árido grueso sí pudo ser determinado.

- La retracción química puede ser disminuida e incluso compensada mediante el uso de aditivos expansivos. La dosificación sin embargo es muy sensible. Con una dosificación muy baja no se observó en este sentido ningún cambio, mientras que una dosificación un poco mayor puede ser peligrosa.

- La retracción química volumétrica de hormigones sellados $(\in \mathrm{V}=0,6 \%)$ representa aprox. sólo un $10 \%$ del valor de la retracción química interna, observada en una pasta de cemento no-sellada. Los resultados obtenidos deben ser por el momento considerados como orientativos, dado que el efecto del sellado en el desarrollo de presiones internas y consecuentemente en el cambio volumétrico no ha sido por ahora investigado.

\section{AGRADECIMIENTOS}

Los autores quisieran agradecer al Dr. R. Beddoe por revisar y corregir el texto en inglés. mentioned, that in this case the final volume contraction is overestimated, because under practical conditions an equalization of pressure always takes place to some extent.

- For unsealed specimens with w/c > 0,40 was found that the absorbed water per cement unit was allways the same independently of the type of mixture. That means, chemical shrinkage is influenced only by the content of cement paste. If the cement content is reduced due to the presence of aggregates, the volumen change is reduced proportionally.

- For sealed specimens the volume change depends on the effect of chemical shrinkage. The influence of different factors, like w/c-ratio, bleeding, aggregates and others difficults the interpretation of the results. However, the restraining effect of coarse aggregate could be determined.

- Chemical shrinkage can be lowered or compensated by expansive additives. The dosage, however, is very sensitive: at a too low dosage no improvement is observed, while at a little bit higher dosage already damaging can occur.

- The bulk chemical shrinkage of sealed concretes $(\epsilon V=0.6 \%)$ represent about only $10 \%$ of the internal chemical shrinkage measured on unsealed cement pastes. However, at present the results should be considered as a guide, since the effect of the sealing on the developed pressures and consequently on volume changes has not yet been investigated.

\section{AKNOWLEDGMENTS}

The authors would like to thank Dr. R. Beddoe for proof reading the english text.

\section{REFERENCIAS REFERENCES}

(1) T. C. POWERS and T. L. BROWNYARD: Bulletin N.² 22 J.ACI (1948).

(2) W. CZERNIN: Über die Schrumpfung des erhärtenden Zements, Zement-Kalk-Gips Nr. 9, pp. 525-530 (1956).

(3) P. CATHARIN: Wechselbeziehung in der Forschung über Zement und Beton, Zement und Beton 21, pp. $98-105$ (1976).

(4) W. CZERNIN: Zementchemie für Bauingenieure, Bauverlag GmbH, Berlin (1977). 
(5) S. ZIEGELDORF and H. K. HILSDORF: Early Autogeneous Shrinkage of Cement Pastes, 7th ICCC, Vol. 4, pp. $333-338$ París (1980).

(6) F. O. SLATE and R. E. MATHEUS: Volume Changes on Setting and Curing of Cement Paste and Concrete from Zero to Seven Days, J. ACl, pp. 34-39 (1967).

(7) N. SETTER and D. M. ROY: Chemical Features of Chemical Shrinkage of Cement Paste, CCR Vol. 8, pp. 623-634 (1978).

(8) A. M. NEVILLE: Properties of Concrete, Pitman Publishing, London (1975).

(9) S. CHATTERJI: Probable Mechanism of Crack Formation at Early Ages of Concretes, Int. Conf. on Concrete of Early Ages, RILEM Session III, pp. 35-38 París (1982).

(10) S. CHATERJI: Drying Shrinkage of Cement Paste and Concrete, CCR Vol. 6, pp. 145-148 (1976).

(11) S. ZIEGELDORF, H. S. MÜLLER, J. PLÖHN and H. K. HILSDORF: Autogeneous Shinkage and Crack Formation in Young Concrete, Int. Conf. on Concrete of Early Ages, RILEM Session III, pp. 83-88 París (1982).

(12) J. BARON, Mme BRACHET-ROLLAND and J. C. PIDOUX: Chois des Ciments pour Diminuer le Risque de Fissuration des Revetements en Beton, Session A-2, pp. 1-44 París (1969).

(13) J. BARON: Mesures du Premier Retrait des Betons Hydrauliques, Int. Col. on The Shrinkage of Hydraulic Concretes, RILEM, I-I Madrid (1968).

(14) K. KOMLOS and L. BRÜLL: Über das Kapillarschwinden von Zementleimen, Mörteln und Betonen, Ton Industrie Zeitung, Vol. 110 N. .11 , pp. $750-755$ (1986).

(15) M. OSSA, C. MARCANTONINI and F. COFRE: Retracción de Pastas de Cemento en Estado Plástico y en la Primera Etapa de Endurecimiento, Materiales de Construcción Vol. 34 N. ${ }^{2} 194$, pp. 25-41 (1984).

(16) W. BRAMESHUBER et al: Der Einfluß des Zementsteinschrumpfens auf die mechanischen Eigenschaften von Beton, Arbeitsbericht U. Karlsruhe (1986).

(17) F. JUNG: Shrinkage due to Hydration and its Relation to Concrete Strength, Int. Col. on The Shrinkage of Hydraulic Concretes, RILEM, IV-C, Madrid (1968).

(18) F. W. LOCHER: Volumenänderung bei der Zementerhärtung, Zement und Beton, Nr. 85/86, pp. $22-25$ (1975).

(19) G. D. de HAAS, P. C. KREIJGER et al: The Shrinkage of Hardening Cement Paste and Mortar, CCR Vol. 5, pp. 295-319 (1975).

(20) C. H. DETRICHE, J. C. MASO: Materiaux et Constructions, Vol. 12 N. ${ }^{9} 69,185$ (1979).

(21) DIN 1164: Portland-, Eisenportland-, Hochofen-, und Traßzement (1978).

(22) H. KÜHL: Die Erhärtung und die Verarbeitung der hydraulischen Bindemittel, Zement-Chemie, Band III, Verlag Technik, Berlin (1952).

(23) L. EBENSPERGER, R. BREITENBÜCHER: Wirksamkeit von Quellzusätzen im Beton zur Kompensation von Zwangsspannungen, Festschrift "Rupert Springenschmid", TU München 1990, pp. 83-99. 